Ankara Üniversitesi Sosyal Bilimler Dergisi | 10(2) | 2019 | 56 - 65

\title{
FINDING THE SELF IN THE OTHERNESS OF NATURE: THE SUNDARBANS AND POSTCOLONIAL IDENTITY IN SALMAN RUSHDIE'S MIDNIGHT'S CHILDREN ${ }^{1}$
}

\section{sostan inturate DERGISI}

ANKARA UNIVERSITY JOURNAL

SOCIAL SCIENCES

10.33537/sobild.2019.10.2.6

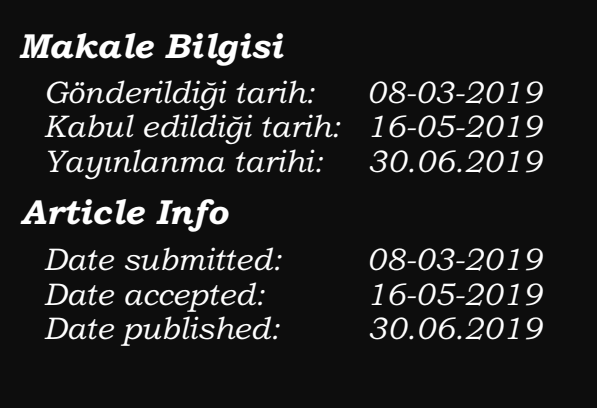

$\ddot{0} z$

\section{SALMAN RUSHDIE'NIN GECEYARISI CCOCUKLARI ESERINDE DOGANIN ÖTEKILIGGINDE KENDINI BULMA: SUNDARBANS VE SÖMÜRGECILIIK SONRASI KIMLIKK}

\section{Önder CETIIN}

Dr. Öğr. Üyesi, Ege Üniversitesi, Edebiyat Fakültesi

Ingiliz Dili ve Edebiyatı Bölümü, cetinonder@gmail.com

\section{Anahtar sözcükler}

Ekoeleștiri, Sömürgecilik Sonrast, Kimlik, Biyolojik Bölgeselcilik, Doğa

\section{Keywords}

Ecocriticism, Postcolonialism, Identity, Bioregionalism, Nature
Doğa ve kültür arasında süregelen bir ikilik olmasına rağmen edebiyat eserlerinde insanlik durumunun belli bazı yönlerini betimlemek ve bilinçaltında nelerin olduğunu göstermek için doğadan yararlanıldığını görürüz. Bu kaçınılmazdır çünkü insan da doğanın bir parçasıdır. Bu insan durumlarindan bir tanesi de savas ve onun sebep olduğu travmadır. Savaşın yol açtığ travma ve tutarsızlık insanın kimliğini sorgulamasina ve hatta kaybetmesine kadar gidebilir ki bu noktada insan bu travmay atlatma ve kimliğini bulma cabası içinde tekrar doğanın sağladiğ sakinliğe dönebilir. Bu fiziki çevre bir orman ya da çöl olabilir. Bu makale Salman Rushdie'nin Geceyartst Çocukları adlı romanının Sundarbans bölümünü eko eleştirel açıdan bir okumasinı yaparak romanın baş karakteri Saleem Sinai'nin kimliğini dünyanın en güzel ve ayn zamanda en tehlikeli ormanlarindan bir tanesinde bulmasinı tartıșayı amaçlamaktadir. Saleem'in 1965 Hindistan-Pakistan savaşinda bir asker olarak kimlik arayıșı onu politik olarak sinırları en çok tartışılan Bangladeş ve Hindistan arasındaki devasa yağmur ormanına götürür. Bu bağlamda, Sundarbans'in muğlaklığ mecazi olarak sömürgecilik sonrası kimliğin muğlaklığına karşılık gelmektedir. Eko eleştiri teorisi temelde fiziksel mekan ile ilgilendiğinden bireysel kimliği odak noktası yapan sömürgecilik sonrası eleştirmenler tarafindan şüpheyle karşilanır. Bu makale, aynı zamanda Saleem'in Sundarbans'ta yaşadıklarından yola çıkarak eko eleştirel ve sömürgecilik sonrası teorilerin farklı araștırma odaklarından kaynaklanan tartışmaları da uzlaşılabilecek ortak bir paydada birleştirmeyi amaçlamaktadır.

1 A different version of this article has been presented in Ecocriticism: New Horizons Conference organized in Antalya in 2009 under the name of "Self-Revelation and Claiming Postcolonial Identity through Nature in Salman Rushdie's Midnight's Children."

\section{Abstract}

Although there is an ongoing dichotomy between nature and culture, works of literature often make use of nature to depict certain aspects of the human condition and reveal what is hidden in the subconscious of the characters. It may be deemed inevitable because humankind is also part of nature. One of these aspects occurs during intense situations like wartime. War, as a state of chaos and instability, offers soldiers a kind of obscurity at times when they find themselves in a constrained experience. Nature, at these moments, plays a crucial role by offering the characters a point of serenity in which they can recover from their trauma and reconstruct their self. This environment may sometimes be a jungle or a desert. This article aims to do an ecocritical reading of "the Sundarbans" chapter of Midnight's Children focusing on Saleem Sinai's search for his identity and finding it in one of the most beautiful and also perilous forests in the world. Saleem's quest as a soldier in the Indo-Pakistani War of 1965 to find who he really is takes him to one of the politically most disputed regions on the border of Bangladesh and India in South Asia. In this respect, the ambiguity of the Sundarbans is a metaphor for the ambiguity of the postcolonial identity. Ecocriticism, which mainly deals with the physical space, is usually approached with doubt by the postcolonial critics who center on the promotion of individual identity. By emphasizing Saleem's experiences in nature in the unique environment of the Sundarbans, this article also aims to reconcile the controversy arising from the diverse aspirations of both ecocriticism and postcolonialism over their research foci. 


\section{INTRODUCTION}

Salman Rushdie's Midnight's Children is a postmodern and post-colonial novel in which magical realist elements are highly used to depict a representation of postcolonial India after its independence in 1947. Although Rushdie is sometimes criticized due to his outsider perspective of India, it was selected the best novel to win the Booker Prize in 1993 (Kortenaar, 1995, p. 3). Among the many underlying themes of Salman Rushdie's Midnight's Children (1980), search for identity plays a particularly crucial role in the course of the novel. The categorization of Midnight's Children as a bildungsroman by critics like Dubravka Juraga helps to describe the efforts of the protagonist, Saleem Sinai, to reclaim his identity as he goes through the crucial social and historical moments of India (1999, pp. 225-49). Saleem admits to his need to mean something by stating: "I must work fast, faster than Scheherazade, if I am to end up meaning - yes, meaning - something. I admit it: above all things, I fear absurdity" (Midnight's Children 9) (Henceforth $M$ 'sC). On the other hand, examining the novel as a bildungsroman is not only redundant but also restrictive. One of the categories that the novel falls into according to many of the critics like Uma Parameswaran (1983), Neil tan Kortenaar (1995), and David Lipscomb (1991) is the categorization of Midnight's Children as a historical novel. As a matter of fact, Saleem confesses his bondage with history from the very beginning of his narrative as he was born on the night of India's independence from British rule. Yet, his bond has magical realist elements as he is one of the one thousand and one children born at the night of independence who have various talents and Saleem is the one child who can gather them telepathically to discuss the plight of the newborn nation. He tells his story to Padma, the help in his Chutney factory, on the verge of death at his thirties, and his efforts to claim his identity must be performed by means of history as he juxtaposes his story alongside the history of India: "I had been mysteriously handcuffed to history, my destinies indissolubly chained to those of my country" (M'sC 9). However, as Michael Reder in "Rewriting History and Identity: The Reinvention of Myth, Epic, and Allegory in Salman Rushdie's Midnight's Children" points out, there is not one history of India. Salman Rushdie creates his own history through the narrative of Saleem Sinai (1999, p. 225).

In his version of Indian history, Saleem provides the reader with the details of his life from the moment India gained independence on August 15, 1947, which is also his birthday, to his early adulthood. However, his life, which is tied to the history of India, is less than tranquil because his destiny is tied to a nation, which is newly founded according to the independence agreement; yet it does not change the fact that it has thousands of years of history, which is partly suppressed by colonialism. Thus, in this ambiguous environment of the new nation, Saleem goes through some significant social and historical moments, which may help to draw on his identity. However, one of the chapters of Saleem's life, which is also one of the chapters of Midnight's Children, presents a real challenge for Saleem Sinai in which nature itself, specifically a bioregion, is utilized to construct identity. Saleem Sinai's family is killed during a bombardment in the Indo-Pakistani War of 1965 and he is stripped of his memories with a blow to his head from a flying spittoon in the same bombardment. Devoid of his memories and rejected by his sister Jamila Singer, he is enlisted in a special unit of the Pakistani army that tracks down the wanted politicians and opposition leaders. His giant nose with a great sense of smell is what makes him special for the mission because he can track anyone. Yet, in one of those missions, Saleem decides to flee in order to find the meaning of his existence, which he mentions in the very beginning of his narrative, dragging three other soldiers who are the members of the special team. Saleem's experiences in the Sundarbans results in his getting bitten by a snake, which will also restore his memories, ergo his identity. Although the chapter figuratively reads like a descent into hell and the snake bite is the story of Adam and Eve reversed, the rules and borders of the Sundarbans are not set by the governments but by nature. Saleem's quest in the mangrove forest can be considered as an example of the construction of the place-based identity in which the individual connects with his past and memories through a physical space that he belongs to. This paper aims to do an ecocritical reading of the Sundarbans chapter and discuss the construction of postcolonial identity of Saleem Sinai in Rushdie's novel by way of connecting to the land. The scope and aim of the thesis will also touch the question whether the Sundarbans chapter is offering a way for both ecocritical theory and postcolonial theory can exist together.

\section{THEORETICAL BACKGROUND}

Ecocriticism as an evolving critical theory investigates in its simplest terms "the relationship between literature and physical environment" (Glotfelty, 1996, p. xviii). The representations of the physical environment in the literary texts are closely connected to how we conceive our world. Therefore, ecocriticism also covers the relationship of humankind to nature. In a more detailed definition of ecocriticism, Scott Slovic defines it as

the study of explicit environmental texts by way of any scholarly approach or, conversely, the scrutiny of ecological implications and human-nature relationships in any literary text, even texts that seem, at first glance, oblivious of the nonhuman world. In other words, any conceivable style of scholarship becomes a form of ecocriticism if it is applied to certain kinds of literary works; and, on 
the other hand, there is not a single literary work anywhere that utterly defies ecocritical interpretation, that is 'off limits' to green reading. (2000, p. 160)

Despite this broader definition by Slovic, ecocriticism sometimes is in the crosshairs due to a lack of anchoring to the literary theory. For example, John Parham in his article titled "The Poverty of Ecocritical Theory" states that "[f]rom its inception ecocriticism adopted a belligerent attitude towards literary theory" (2008, p. 25). Parham construes the statement of Cheryl Glotfelty in her introduction to The Ecocriticism Reader "polemical" as she states that "if your knowledge of the outside world were limited to what you could infer from the major publications of the literary profession, you would quickly discern that race, class, and gender were the hot topics of the late twentieth century, but you would never suspect that the earth's life support systems were under stress" (1996, p. xvi). Yet, Axel Goodbody and Kate Rigby in their "Introduction" to Ecocritical Theory: New European Approaches claim that "the oft-repeated allegation that, until recently, ecocriticism has been universally atheoretical is misleading" since "it overlooks some valuable early forays into ecocritical theorization, such as those of Patrick Murphy, who effectively harnessed Bakhtinian dialogics to the practice of ecofeminist criticism" (2011, p. 1). In the final analysis, the interdisciplinary nature of ecocriticism makes it possible to analyze any kind of text that has environmental implications and derive conclusions as to the place of humankind in the grand design.

As a branch rooting out of ecocritical theory, postcolonial ecocriticism is one of the disputed fields of study as it takes its subject matter from the culture and land of the once colonized people. The reconciliation of ecocritical and postcolonial theories has been the subject of considerable scholarly work recently. Trying to identify the tensions between these two theories, Elizabeth M. DeLoughrey points out that

postcolonial criticism often tends to leave out the environmental factors in trying to recover national identity. On the other hand, ecocriticism does not tend to bring forth the historical and social details of the place, which is an intolerable gap in postcolonial theory. Underestimation of the historical and social specificities of place by ecocriticism has not helped to close the gap between ecocritical and postcolonial theories (DeLoughrey, Gosson, \& Handley, 2005, p. 5).

There is little doubt that ecocriticism and postcolonialism can make use of their particular insights in order to shape what Fiona Barnes calls "the cultural and political ramifications of geography, the socalled sense of place and a sustained ecocritical focus on the ways in which race, gender, and other social vectors help constitute environmental experience" (in DeLoughrey, Gosson, \& Handley, p. 5).

It is important to understand the concerns of postcolonialists and ecocritics in order to find common grounds in their reconciliation. On a more profound level, Rob Nixon in his "Environmentalism and Postcolonialism" presents four main detailed differences between these two areas of criticism. Focusing on hybridity and cross-culturation on the part of poscolonialists can be considered as the first distinction whereas ecocriticism revolves around the discourse of purity. Second, postcolonialism favors displacement, while literary works accepted, as "environmental" tend to focus on the "literature of place." Another point of difference is that postcolonialists are consistently critical of nationalism; however, ecocritical theory and masterpieces of environmental literary writing are sometimes rooted deeply in a national core. A final distinction may be that postcolonialism tends to dig deep into the past and bring up the images of peripheral experience through the memory of transnational migrants, while in environmental literature, the history is concealed and silenced, transforming it into a quest of "timeless, solitary moments of communion with nature" (Nixon, 2005, p. 235). In drawing the borders of the problem between postcolonialism and ecocriticism, it becomes obvious that displacement and history which postcolonialists try to emphasize as the main traits and the ethics of place which is favored by ecocritics cannot be brought into equal terms to work together with attributing a notion that foregrounds only the environment.

Another critic who dwells on the concerns between postcolonialism and postcolonial ecocriticism is Timothy Clark. In The Cambridge Introduction to Literature and the Environment, he states, "in the encounter between 'post-colonial' thinking and ecocriticism to date, it is ecocriticism that first seems the more in need of revision. For, to many people, modern environmentalism can look like another form of colonialism" (2011, p. 120). He grounds his argument on the notion that "reform environmentalism has become part of a system of global managerialism, closely related to institutions like the IMF or the World Bank, with its Global Environmental Facility" (Clark, 2011, p. 120). Furthermore, Clark contemplates on how to integrate ecocritical arguments to postcolonial questions and remarks, "postcolonial critics question the way some environmental thinkers refer simply to 'humanity' as the antagonist of the natural world, a view that ignores vast differences between human groups" (2011, p. 122).

Among the criticism directed towards ecocriticism, one of the possible suggestions to reconcile the gap between postcolonial and ecocritical theories may be bioregionalism which, in Jay Parini's words, "is a responsiveness to one's local part of the earth whose 
boundaries are determined by a location's natural characteristics rather than arbitrary administrative boundaries" (in Nixon, p. 236). Parini's definition might offer a solution to the problematic distinction between displacement and ethics of place by eliminating the anthropocentric characteristics like government and history in the evaluation of environmental considerations of postcolonialism. In order to understand bioregionalism on a more profound level, it would be appropriate to view the definition of Gary Snyder:

In the old ways, the flora and fauna and landforms are part of the culture. The world of culture and nature, which is actual, is almost a shadow world now, and the insubstantial world of political jurisdictions and rarefied economies is what passes for reality. We live in backwards time. We can regain some small sense of that old membership by discovering the original lineaments of our land and steering - at least in the home territory and in the mind - by those rather than the borders of arbitrary nations, states, and counties. (1990, p. 37)(Emphasis original)

Snyder's ideas, which represent a land ethic freed from social and cultural infrastructures such as states and governments, may be regarded as almost impossible but, on a personal level, we can try to identify our environment as we try to understand ourselves. These personal explorations when brought up together may lead to the land ethic Snyder favors, defining the land according to the rules it sets for people. In fact, Lawrence Buell echoes this in The Environmental Imagination when he writes "the nonhuman environment is present merely as a framing device but as a presence that begins to suggest that human history is implicated in natural history" (1995, pp. 7-8). Yet, to free the land from the bond of any government treaty or act and respect that local environment by its natural presence might have its problems from the perspective of postcolonial theory since, as Nixon states,

concentric rings of the bioregionalists more often open out into transcendentalism then into transnationalism.... In this way, a prodigious amount of American environmental writing and criticism makes expansive gestures while remarking amnesiac toward non-American geographies that vanish over the intellectual skyline (2005, p. 236)

Despite their differences discussed above, postcolonialism and ecocriticism have a common ground of investigation, which is colonialism. During the colonial period, both indigenous people and environment were affected, transformed and at times devastated. However, colonialism may not be over and postcolonialism is another veiled period in which indigenous people as well as land, animals and other non-humans are abused. As Mukherjee suggests,

I take 'postcolonial' not as the sign of a clean historical break between the era of modern Euronorth American colonial domination and that of Asian, African, Latin American and Oceanic national self-determination; but rather as a historical condition of intensified and sustained exploitation of the majority of humans and nonhumans of the former colonies by a cartel composed of their own and 'core' metropolitan European/north American elites. That is to say, the 'post' in postcolonial marks not an end of colonialism, but an end of a particular mode of colonialism, which then shifts its gears and evolves to another stage (obviously triggering a concomitant shift in the global struggles against it). (2010, pp 5-6)

In this new type of neocolonialism triggered by global capitalism, postcolonialism inevitably becomes green due to the negative impact of neocolonialism on the environment, which is closely associated to the living styles and standards of the postcolonial countries. Graham Huggan in his 2004 article emphasizes that "the 'green' turn in postcolonialism was in effect a sign of the scholars' admission that it was impossible to analyze modern imperialism and colonialism without engaging with the massive scale of environmental devastation that they entail (in Mukherjee, p. 39). In Postcolonial Ecocriticism, Huggan and Tiffin once again suggests that to overcome the problems between postcolonialism and ecocriticism, it is imperative to maintain that the "proper subject of postcolonialism is colonialism, and to look accordingly for the colonial/imperial underpinnings of environmental practices in both 'colonizing' and 'colonized' societies of the present and the past" (2010, p.3). Postcolonial ecocriticism, which is another branch of the ecocritical theory trying to eliminate the differences between the two theories, "performs an advocacy function both in relation to the real world(s) it inhabits and to the imaginary spaces it opens up for contemplation of how the real world might be transformed" (Huggan and Tiffin, 2010, p.13). In accordance with Huggan and Tiffin's discussion, Mukherjee also comments that even if postcolonialism and ecocriticism become contradicting over their engagement of the global debates about the environment, the solution to these conflicts will also arise within them:

[P]ostcolonial green', 'eco postcolonialism' and the like, I think will have to strengthen and revive the conceptual importance of the philosophical perspective of historical materialism that has been implicit in much of the 'social ecological' and second wave postcolonial positions. The history of this philosophical position, in its modern 
incarnation at least, stretches back to the radical wing of the European Enlightenment. A careful mining of the materialist seams of ecological thinking will not only make eco-criticism more analytically robust, but will also make its corrective contribution to postcolonial studies more meaningful. (Mukherjee, 2010, p.58)

History and material world are two aspects of postcolonialism and ecocriticism and the degree of emphasis that will be given to these concepts will determine the future of the postcolonial ecocriticism.

In the light of the theoretical background, Saleem Sinai's life in the Sundarbans may be interpreted as an act of self-exploration through a place, which, in this particular example, is the unique wetland of the rainforest separating India and Bangladesh. As much as it seems that Saleem benefits from nature, which points to a more psychological aspect of human-nature relationship, Sundurbans represents both history and the material world as discussed above, and it brings the postcolonial subject both with the history of the country and its material environment.

\section{DISCUSSION}

In Midnight's Children, the protagonist Saleem Sinai's life and identity is compartmentalized throughout the novel. In every one of these compartments, Saleem falls apart and then gathers his parts together after the historical and social events that the independent India goes through, to which he claims his destiny is attached. The shaping of Saleem's identity starts long before he was born as Rushdie inherits the narrative style of Laurence Sterne's Tristram Shandy in the novel. Saleem begins his narration with the story of his grandfather and later on his own family long before he was born at the exact night of India's independence from the British colonial rule. Saleem's grandfather, Aadam Aziz, who has studied medicine in Heidelberg, Germany is an outsider to his own people in his village. Aadam falls in love with Naseem, who will become Saleem's grandmother behind a perforated sheet as he is called to examine her from time to time. He falls in love with one of her parts each time due to the limitations of the perforated sheet. Saleem's narrative also highlights his family, Amina and Ahmed Sinai, who are depicted by Saleem as British wannabes since they buy an estate from a British gentleman called $\mathrm{Mr}$. Methwold, who prepares to leave Bombay as the partition of India approaches. However, Mr. Methwold has an agenda to turn the Sinai family into a British family and even after he sells the estate, he visits them regularly and imposes his traditions such as giving cocktails every evening at six o'clock. Saleem is born into a hybrid neighborhood in which the villas are named after the palaces of Europe, but the inhabitants are all Indians. Yet, it is not only his upbringing that drags Saleem into a hybrid identity but also his disproportionate outlook, especially his nose. He says, "I, Saleem Sinai, later variously called Snotnose, Stainface, Baldy, Sniffer, Buddha and even Piece- ofthe-Moon, had become heavily embroiled in Fate - at the best of times a dangerous sort of involvement" ( $M$ 's $C$ 9). Saleem's life is a life of transformation and some of the nicknames he is dubbed at certain points of his life are the results of these incidents.

One of these incidents occurs during his escape to the Sundarbans, in which he tracks anti-government officials as part of a military squadron. With social and political turmoil during India's independence, its relationship with Pakistan has been in focus due to the disputed areas on the border of these two countries. Saleem, who was born in Bombay into a Muslim family had to immigrate to Pakistan due to the religious suppression. It is inevitable for Saleem to escape the history since he claims his destiny is tied to India's. Indo-Pakistani War of 1965 is one the conflicts between the two countries and Saleem and all his family is affected by the bombardments of Indian fighterbombers. Saleem Sinai becomes numb and loses his memory with a bomb meant for an oil factory. He says, “... I am stripped of past present memory time shame and love, a fleeting but also timeless explosion in which I bow my head yes I acquiesce yes in the necessity of the blow, and then I am empty and free, because all the Saleems go pouring out of me..." (M'sC 343). Five years after this catastrophic incident that obliterates his entire family except his sister, the reader finds Saleem in a special unit of the Pakistani army numbed and without memory. This unit is called "Canine Unit for Tracking and Intelligence Activities" (M'sC 347) and Saleem's quest starts with a mission on 25 March 1971 after the negotiations between India and Pakistan come to an end. Saleem and his friends from their military unit, Shaheed, Ayooba and Farooq, are sent to India to "track down minor Awami League Officials and well-known Communist types" (M'sC 365). However, it seems like a never-ending mission "as though some invisible force were directing their footsteps, drawing them into a darker heart of madness" because "their mission sends them south south south, always nearer to the sea, to the mouths of Ganges and the sea" (M'sC 358). They get hold of a boat because Saleem says the trail goes down the river. As they row their boat, it is no more a tracking mission but a journey into the unknown regardless of date and time:

But there is still the meaningless chase, the enemy who will never be seen, and the buddha, "Go that way," and the four of them row on south, south south south, they have murdered the hours and forgotten the date, they no longer know if they are chasing after or running from, but whichever it is that pushes them is bringing them closer closer to the impossible green wall, "That way," the buddha insists, and then they are inside it, the jungle 
which is so thick that history has hardly ever found the way in. The Sundarbans: it swallows them up. (M'sC 359)

The mission of tracking political escapees turns into a way of finding one's self as Saleem is void of all the memories of his past life. He is drawn into the ambiguity of the Sundarbans as a place that also contains multitudes like India. The Sundarbans, a place, which is so dense and pre-historic, embraces them in their quest. In this search for identity, this unique rain forest presents the reader with a bioregion, in which nature defines the rules. A. Jalai depicts this unique environment as such:

On the southern tip of West Bengal in eastern India, just south of Calcutta, the great river Ganges fans out into many tributaries over a vast delta before ending a journey that began in the distant Himalayan north with a plunge into the Bay of Bengal. The mouth of this delta is made up of about three hundred small islands, spread over an area of about ten thousand square kilometers and straddling India's border with Bangladesh. It is one of those areas of the world where the lie of the land mocks the absurdity of international treaties, because it is virtually impossible to enforce border laws on a territory that constantly shifts, submerges and resurfaces with the ebb and flow of the tide.... These are the Sundarbans - the forests of beauty. (in Mukherjee, p. 108)

Saleem flees to 'the forests of beauty' in order to reconnect to his homeland, India despite his family and Saleem are profoundly affected by the war between Pakistan and India. With regard to Saleem's search for identity, Giles Gunn suggests in Interpretation of Otherness that "Modern man tends to view the encounter with 'otherness'... as a mode of access to possibilities of change and development within the self and the self's relation to whatever is experienced as 'other"' (in Slovic, 1996, p. 352). Saleem as the other, in this case, chooses to find his self in the otherness of the Sundarbans. First of all, Saleem's otherness comes from his birth into postcolonial India. Although he was born in India, religion is another factor that makes him and his family the 'Other' and because of the religious conflict, they had to move to Pakistan. Another aspect of his otherness results from his being switched with another baby on the night he was born. Mary Pereira who is the night nurse at Dr. Narlikar's Nursing Home, switches the baby of Amina and Ahmed Sinai with the out of wedlock baby of Vaneta and Mr. Methwold. Vaneta is the wife of Wee Willie Winkie, a street singer, who frequents the villas with his son Shiva, who is actually the child of Sinai's. The truth is revealed at Saleem's eleventh birthday as he needs a blood transfusion due to an accident, yet neither his mother nor his father is a match and Mary, who looks after
Saleem at that time, confesses her crime on the night of the Partition. Because of all the above examples, Saleem refers to the bombardment in the Indo-Pakistani war of 1965, which results in the loss of his memory, as purification. It is also ironic and remarkable how Saleem is purified from his traumatic past, which also reflects the chaotic history of India. The bombs, which strip him from his memories of his traumatic past, are the products of anthropocentric culture and technology. Yet, Saleem is in need of "ending up with meaning" which means that he needs to remember his traumatic past in order to achieve this end. Five years without memory, he believes that the land, the Sundarbans, can provide that meaning by reconnecting to the archaic forests of beauty.

As another compartment in Saleem's life, he has to claim his identity back during his time in the Sundarbans. Michael Reder emphasizes that Saleem constructs a completely different history from the perspective of an individual that undermines the kind of history that often comes before the experiences of individuals who are the real habitants of a nation (1999, p. 226). As history plays a crucial role in reclaiming one's identity, Saleem also admits that he has to run away from the history he is handcuffed to:

\begin{abstract}
Although I'm well aware that I am providing any future commentator or venom-quilled critics (to whom I say: twice before, I've been subjected to snake-poison; on both occasions, I proved stronger than venenes) with yet more ammunition - through admission of guilt, revelation-of-moral-turpitude, proof-of-cowardice - I'm bound to say that he, the budha, ${ }^{2}$ finally incapable of continuing in the submissive performance of his duty, took to his heels and fled. Infected by the soul-chewing maggots of pessimism futility shame, he deserted, into the historyless anonymity of rain forests, dragging three children in his wake. (M'sC 360)
\end{abstract}

Saleem's escape to "the historyless anonymity of rain-forests" suggests that Saleem's reconnection to his postcolonial identity will be through nature. The text takes a trajectory closer to that of the ecocritical theory, which, as mentioned earlier, sometimes tends to dismiss or subordinate history "to the pursuit of timeless, solitary moments of communion with nature" (Nixon, 2005 , p. 235). On a different level, this return to the land may be interpreted as closing the gap between favoring the displacement on the part of postcolonial theory and giving "priority to the literature of place" (Nixon, 2005, p. 235). Saleem in the Sundarbans is released from the handcuffs of history to which he has been attached since the moment he was born. He finds refuge in an environment, which can be defined neither

2 Saleem's nickname that was given by the members of his friends in the military unit meaning 'old man.' 
by political discussions nor by history because of the timeless existence of the Sundarbans, which is ruled by the tidal waves shaping the land according to the planetary movements of the moon and the earth. The rainforest becomes the unique place in which Saleem reclaims his identity.

The specific geographical position of the Sundarbans, which calls for a recognition as a crucial bioregion, makes it easier to explain why Saleem seeks refuge in the rainforest in order to identify who he is in the course of his life. Gary Snyder maintains that "to know the spirit of a place is to realize that you are a part of a part and that the whole is made of parts, each of which is whole. You start with the part you are whole in" (1990, p. 40). With regard to Snyder's comment, Saleem as an individual who has lost his senses and memories tries to connect to the land as an act of regaining his memories and identity consequently. He feels that he is part of the Sundarbans, and the invisible force that leads them into the jungle is merely Saleem's demand to reconnect to himself.

Yet, the Sundarbans does not offer a "solitary" atmosphere for Saleem Sinai and his friends. As Cynthia Deitering states, in "The Postnatural Novel,"

the novel of the 1980s reflects a world in which the air is in fact no longer necessarily life-sustaining. Nature in these novels is usually extraneous to the Real, though often it evokes nostalgia and a sense of exile, for the planet itself no longer feels like home to a number of characters: the private experiences which formed their metaphysical definitions of home are no longer available in the 1980s. (1996, s. 201)

As mentioned earlier, Saleem's life has been partitioned into different compartments thorough the historical and social events taking place after India's independence in 1947. From this perspective, the Sundarbans may be projected as another compartment in Saleem's life that he has to pass through especially after he suffers from memory loss and numbness. Although it seems like another ordinary phase of his life in which he is dragged from one place to another in the flux of history, the Sundarbans do not offer an easy way for Saleem to attain his identity and there is turmoil awaiting Saleem and his friends. Neil Ten Kortenaar comments on this journey into the rainforests as follows:

The culmination of the amnesia is the journey to the Sundarbans, a figurative descent into Hell. The Sundarbans, a jungle area in the Ganges delta, belong to a time before earth and sea are divided, to the "primeval world" from which selves and nations emerge, before mirrors, "before clock towers" and time, before words. (1995, pp. 220221)
Although the rainforests are compared to Hell, the use of the rainforests as a place of perdition is one of the characteristics of a place that supports self-discovery. The scene of Saleem's entrance to the jungle might give a clue about things that the jungle has to offer him: "the jungle closed behind them like a tomb, and after hours of increasingly weary but also frenzied rowing through incomprehensibly labyrinthine salt-water channels overtowered by the cathedral-arching trees, Ayooba Shaheed Farooq were hopelessly lost" (M'sC 360). Although the Sundarbans may literally be translated as "beautiful jungle" in the Bengali language, Saleem and his friends are in exile from the world that does not feel like home anymore, as Deitering's (1996) suggests in her discussion of novels of the 1980s. Moreover, the creepy atmosphere emerges even more strongly when the last light of the day is lost because "as the mystery of evening compounded the unreality of the trees, the Sundarbans began to grow in the rain" (M'sC 361).

As much as the Sundarbans chapter reads like a descent to hell and a reversal of Adam and Eve story, this return to the land can be defined as "the process of rediscovering human connections to the land" (Lindholdt, 2003, p. 244). As Saleem marches into the jungle with his friends, he crosses the borders that separate nature and humankind; however, this passing is done for a particular reason on the part of Saleem because he wants to find the meaning of his existence and believes that the rainforests will provide him with the answer if he makes a connection with the land. The journey into the Sundarbans reminds us of the notion presented by Gary Snyder when he comments on distinct worlds of nature and culture which are isolated from the world of politics and governments that stands for reality (1990, p. 37).

Building on this issue, the Sundarbans, with regard to the notion of bioregionalism, presents Saleem with a unique place to make connections with the land in order to "begin an understanding of the self" (Thomashow, 1995, p. 60). However, the rainforests represent a magic completely different from the magical realist elements of the novel. This is a magic that

belongs to an objective world characterized by floes and currents which dwarf the individual altogether.... In the permeable world of the jungle, the boundaries separating inside from outside, states from states, and selves from each other are rendered absurd. Saleem, amnesiac and emotionally numb when he enters the region, is terrified of becoming wholly transparent, a green thought in a green world. (Kortenaar, 1995, p. 221)

While the magical atmosphere of the rainforests suggested by Kortenaar may be linked to the uniqueness of the Sundarbans bioregion and Rushdie's intention to promote such environment in order to achieve the end that is suggested by bioregionalists, it will not be 
unreasonable to point to the fact that Rushdie also tries to establish his character's identity by presenting the rainforests as a place of suffering, self-revelation, and purification. This phenomenon becomes clear once the characters find themselves covered with leeches

which were almost entirely colorless owing to the absence of direct sunlight, but which had now turned bright red because they were full of blood, and which, one by one, exploded on the bodies of the four human beings, being too greedy to stop sucking when they were full. Blood trickled down legs and on to the forest floor; the jungle sucked it in, and knew what they were like. (M'sC 362)

When considered from a logical point of view, the leeches, which are natural inhabitants of the rainforests and can be found in such an environment that is isolated from human interference, become the objects of horror on the part of Saleem and his friends. At this specific point, they become the agents through which Saleem and his friends make a connection with the land. All in all, the jungle grows bigger as four soldiers march deeper into the heart of this dense rainforest. Another similar example appears as they get rid of the leeches and realize they are thirsty and hungry. They drink the rainwater to hydrate and again internalize some part of the rainforests because the water comes

by way of sundri leaves and mangrove branches and nipa fronds, it acquired on its journey something of the insanity of the jungle, so that as they drank they fell deeper and deeper into the thralldom of that livid green world where the birds had voices like creaking wood and all the snakes were blind. (M'sC 362)

Drinking the water coming from the leaves of the trees, which is the natural flora of the rainforests, is one of the ways that nature finds its way into the four young soldiers. Yet, it is better to draw a line and be skeptical about the issue of insanity of the jungle in this representation. First of all, Saleem Sinai and his friends belong to a nation that is the object of confusion and chaos, which is typical for a postcolonial country. Second, they come from a troubled life: on one hand, Saleem, who has already lost his memory and sense of feeling along with his identity, and on the other hand, we have his friends' problematic pasts. Therefore, it might as well be suitable to claim that it is their "insanity" that makes the rainforests seems like such a chaotic environment. For example, Saleem's friends begin to see apparitions about their past lives and deeds. To illustrate, Shaheed, Farooq, and Ayooba, dream about the deeds they have done during past missions as they see

the accusing eyes of the wives of men they had tracked down and seized, the screaming and monkey-gibbering of children left fatherless by their work... and in this first time, the time of punishment, even the impassive budha ${ }^{3}$ with his citified voice was obliged to confess that he, too, had taken to waking up at night to find the forest closing in upon him like a vice, so that he felt unable to breathe. (M'sC 363)

This quotation, which reverberate Kortenaar's comment on Saleem's journey as "a journey into Hell," actually pinpoints the disturbed consciousness of Saleem and his friends in the war. The gloomy and unique atmosphere of the rainforest provides especially Saleem with a challenge to cope up with the extraordinary environmental factors such as tidal waves and monsoon rains which project the rainforest other than what it really is. The metaphor of Hell can actually be observed as the light dies away and

there could be no doubt that the jungle was gaining in size, power and ferocity; the huge stilt-roots of vast ancient mangrove trees could be seen snaking about thirstily in the dusk, sucking in the rain and becoming thicker than elephants' trunks, while the mangroves were getting so tall that, as Shaheed Dar said afterwards, the birds at the top must have been able to sing to God. (M'sC 361)

Shaheed Dar's observation about the mangrove trees arching up to the sky so that they can sing to God suggests that they are far away from heaven and closer to the crust of the earth. These hallucinations they see while they are asleep as a punishment for what they have done are also significant evidence that they are going through hell in the rainforests. At some point, when "they were all trembling shadows of the people they had once been," they begin to see the visions of their relatives. To illustrate, Farooq, "at dusk one day thought he saw his brother running wildly through the forest and became convinced that his father had died" (M'sC 363). Shaheed also gets his share from the nightmares the forest presents them as he "was visited by a monkey with the face of an ancestor; but all he saw was a father who had instructed him to earn his name" (M'sC 364).

Among these visions, which are both nostalgic and nightmarish, Saleem is the one who is the least affected; however, he will make a connection to the land which will restore his memory and his sense of self. In Saleem's case, the revelation occurs by way of a serpent that bites him from his heel as he sits under a sundritree. The snakebite, which makes him comatose for a few days, will restore his memories and his sense of history while his friends wait on him to die of the snake poison. As Saleem's memory is restored,

\footnotetext{
3 Saleem calls himself buddha in this particular chapter beacuse he cannot remember who he is due to amnesia.
} 
his words flowed so freely that they seemed to be an aspect of the monsoon. The child-soldiers listened, spellbound, to the stories issuing from his mouth, beginning with a birth at midnight, and continuing unstoppably, because he was reclaiming everything, all of it, all lost histories, all the myriad complex processes that go to make a man. (M'sC 364-365)

At this specific moment of revelation, it is of crucial importance to underline that Saleem's memories do not come back via hallucination or visions he sees but as the result of a snakebite. As this reconnection to the land is certainly a powerful one, it would be appropriate to say that Saleem's whole journey from the moment he flees and enters the Sundarbans and reclaims his identity is substantial, restoring all the memories he has lost.

After Saleem gains his sense of self and history, they start believing that they hear "the lamentations of families from whose bosom they had torn what once, they had termed 'undesirable elements"' (M'sC 365). In order to prevent these noises, they plug their ears with "the mud of the dream-forest, which no doubt also contained the concealed translucency of jungle-insects and the devilry of bright orange bird-droppings" ( $M$ 's $C$ 366). Saleem and his three soldier friends experience such nightmarish visions due to their troubled subconscious, which is both the result of their traumatic military actions and social, economic and cultural backgrounds that are shaped by the fluxes of the postcolonial period.

The Sundarbans presents a very suitable environment with its unique fauna and flora to create a place in which the protagonist experiences purification from his past life. Saleem's escape to the Sundarbans to claim his identity can be viewed as a postcolonial trait because the rainforests are perceived as the focus of ambiguity due to their geographical characteristics and their place in the colonial history. Although they represent displacement for the postcolonial critics, the Sundarbans become a place, regardless of its history, in which Saleem recollects his memories to be able to "end up meaning something." By favoring a unique environment, which belongs neither to Pakistan nor India, reminding us of the bioregional agenda of Gary Snyder Saleem lets this bioregion shape him.

\section{CONCLUSION}

All in all, it may be concluded that the Sundarbans chapter, apart from the Biblical allusions to the story of the Adam and Eve, can be read in the light of ecocritical theory in the sense that Saleem can only restore his memories and identity after he roots himself to the landscape. The reclaiming of the identity in Midnight's Children is closely associated with the idea of returning to nature. By exploring his otherness in the otherness of another realm, Saleem comes out of the Sundarbans with a full of sense of self and history that he lost in the ambiguity of the postcolonial world. Therefore, as I have tried to emphasize throughout my article, the function of nature in literature and especially in Midnight's Children cannot be overlooked from the perspective of postcolonial and ecocritical perspectives separately since the novel prepares the possible grounds to develop reconciliation between these two theories. While, as Rob Nixon suggests, environmental theorists do not easily follow the transnational thinking, which gained strength in various other disciplines that were central to the developing of greening of the humanities such as history, geography, and anthropology, postcolonial literary critics have kept a certain distance, thinking that environmental issues belong to a higher level of the society (Nixon, 2005, p. 242). As discussed earlier, some critics approach ecocriticism with caution with the idea that environmentalism is another project of the capitalist era. However, Saleem in Midnight's Children proves that human beings can return to the land even if they are postcolonial subjects. The land, the Sundarbans specifically, for Saleem does not represent displacement. Despite their forced immigration from India and his loss of family and memories due to the Indian bombs during the war, Saleem finds refuge in the rainforests that divides the two countries and comes out of it as a complete individual who is purified of his chaotic past. The interdisciplinary nature of ecocritical theory is a very productive catalyst in terms of bringing a variety of disciplines and unite these sub-disciplines into its working grounds and creating awareness towards the environmental problems. The literary reaction between postcolonialism and ecocriticism might lead to the elimination of the prejudices against ecocriticism rooted in the suspicions of the postcolonial critics that it brings forth the land rather than the individual and identity. Therefore, Midnight's Children provides a good opportunity for both postcolonial and environmental critics to evaluate the chances of reconciliation between postcolonial authenticity and environmental concerns through Saleem's character and to see how both of them can be used together to promote a unique environment and identity.

\section{Bibliography}

Buell, L. (1995). The Environmental Imagination: Thoreau, Nature Writing, and the Formation of American Culture. Cambridge: Harvard UP.

Clark, T. (2011). The Cambridge Introduction to Literature and the Environment. Cambridge: Cambridge UP.

Deitering, C. (1996). "The Postnatural Novel: Toxic Consciousness in Fiction of the 1980s". Eds. C. Glotfelty, \& H. Fromm in The Ecocriticism 
Reader: Landmarks in Literary Ecology (s. 196203). Athens: U of Georgia P.

DeLoughrey, E., Gosson, R., \& Handley, G. (2005). Caribbean Literature and the Environment: Between Nature and Culture. Charlottesville: U. of Virginia P.

Glotfelty, C. (1996). The Ecocritcisim Reader: Landmarks in Literary Ecology. Eds. H. Fromm, \& C. Glotfelty. Athens, Georgia: U of Georgia P.

Goodbody, A., \& Rigby, K. (2011). Ecocritical Theory: New European Approaches. Charlottesville: U of Virginia $\mathrm{P}$.

Huggan, G. (2004), 'Greening Postcolonialism: Ecocritical Perspectives', Modern Fiction Studies, 50 (3): 701-33.

Huggan, G., \& Tiffin, H. (2010). Postcolonial Ecocriticism: Literature, Animals, Environment. London: Routledge.

Juraga, D. (1999). "The Mirror of Us All’: Midnight's Children and the Twentieth-Century Bildungsroman.". In M. K. Booker, Critical Essays on Salman Rushdie (pp. 225-49). New York: G.K. Hall.

Kortenaar, N. t. (1995). "Midnight's Children and the Allegory of History". Ariel(2), 41-62.

Lindholdt, P. (2003). "Literary Activism and the Bioregional Agenda.". In M. P. Branch, \& S. Slovic, The ISLE Reader: Ecocriticism, 1993-2003 (pp. 243-57). Athens: U of Georgia P.

Lipscomb, D. (1991). "Caught in a Strange Middle Ground: Contesting History in Salman Rushdie's Midnight's Children.” Diaspora, 1(2), 163-88.

Mukherjee, U. P. (2010). Postcolonial Environments: Nature, Culture and the Contemporary Indian Novel in English. New York: Palgrave MacMillan.

Nixon, R. (2005). "Environmentalism and Postcolonialism.”. In A. Loomba, Postcolonial Studies and Beyond. (pp. 233-251). Durham, NC: Duke UP.

Parameswaran, U. (1983). "Handcuffed to History: Salman Rushdie's Art”. Ariel(14), 34-45.

Parham, J. (2008). "The Poverty of Ecocritical Theory: E. P. Thompson and the British Perspective. (W. Wheeler, \& H. Dunkerley) New Formations , 2536.
Reder, M. (1999). "Rewriting History and Identity: The Reinvention of Myth, Epic, and Allegory in Salman Rushdie's Midnight's Children.". In M. K. Booker, Critical Essays on Salman Rushdie (pp. 225-49). New York: G.K. Hall.

Rushdie, S. (1995). Midnight's Children. London: Vintage.

Rushdie, S. (2004). Self, Nation, Text in Salman Rushdie's Midnight's Children. London: McGillQueen's UP.

Slovic, S. (1996). "Nature Writing and Environmental Psychology: The Interiority of Outdoor Experience". In C. Glotfelty, \& H. Fromm, The Ecocriticism Reader: Landmarks in Literary Ecology (pp. 351-70). Athens: U of Georgia P.

Slovic, S. (2000). Ecocriticism: Containing Multitudes, Practising Doctrine. In L. Coupe, The Green Studies Reader: From Romanticism to Ecocriticism (p. 160-162). New York: Routledge.

Snyder, G. (1990). The Practice of the Wild. San Francisco: North Point.

Thomashow, M. (1995). Ecological Identity: Becoming a Reflective Environmentalist. Cambridge: MIT P. 